\title{
PENYULUHAN PADA PETUGAS KUSTA TENTANG PENTINGNYA FAKTOR PENINGKATAN PELAYANAN KESEHATAN UNTUK MENCEGAH TERJADINYA INFEKSI KUSTA DI DAERAH ENDEMIS KUSTA
}

\section{EDUCATION TO LEPROSY OFFICERS ABOUT THE IMPORTANCE OF HEALTH SERVICE IMPROVEMENT FACTORS TO PREVENT THE OCCURENCE OF LEPROSY INFECTION IN LEPROSY ENDEMIS AREAS}

\author{
${ }^{1}$ Flora Ramona Sigit Prakoeswa. ${ }^{2}$ Erlita Puspitasari \\ ${ }^{1}$ Staff Departemen Ilmu Kesehatan Kulit dan Kelamin, Fakultas Kedokteran, Universitas \\ Muhammadiyah Surakarta \\ ${ }^{2}$ Analis Laboratorium Sentral Instalasi Patologi Klinik, RSUD. Dr. Soetomo Surabaya \\ Korespondensi: Flora Ramona. Alamat email: frsp291@ums.ac.id
}

\begin{abstract}
ABSTRAK
Prevalensi kusta tahun 2018 sebesar 1,5/10.000 di Kabupaten Tuban. Program eliminasi kusta dengan menggunakan metode Multi Drug Treatment (MDT) dari WHO telah dilaksanakan, namun masih ditemukan kasus baru infeksi kusta. Hal tersebut dipengaruhi oleh aspek antropologis dan sosial, yang berpengaruh pada sistem makro (kebijakan pemerintah), meso (lingkungan sekitar), maupun mikro (hospes dan sistem imunitas), salah satunya adalah kualitas pelayanan kesehatan oleh para petugas kusta. Dilaksanakan penyuluhan di Kantor Dinas Kesehatan Kabupaten Tuban yang merupakan salah satu daerah kantong endemis kusta di Jawa Timur. Upaya ini merupakan salah satu strategi pengendalian penyakit kusta dan upaya pencegahan guna memutus rantai penularan kusta dengan cara meningkatkan pelayanan kesehatan di daerah endemis kusta. Penyuluhan ini diikuti oleh 15 peserta merupakan perwakilan tiap puskesmas di wilayah Kabupaten Tuban. Penyuluhan dilakukan dengan cara konseling, diskusi, dan tanya-jawab tentang pentingnya peningkatan kualitas pelayanan kesehatan sebagai salah satu cara untuk mencegah terjadinya infeksi kusta di daerah endemis kusta.Untuk mengukur pemahaman sebelum dan setelah penyuluhan dilakukan "one group pre and post test design". Data yang didapatkan dianalisis dengan uji Wilcoxon menggunakan SPSS. Dari hasil analisis didapatkan rerata nilai pre tes sebesar 68,67 $\pm 9,15$, sedangkan mean/rerata nilai post-test sebesar 93,33 \pm 8,16. Hasil uji Wilcoxon didapatkan seluruh peserta mengalami peningkatan pemahaman (nilai $p$ 0,001). Kesimpulan dari penelitian ini terdapat peningkatan pemahaman petugas pelayanan kesehatan setelah dilakukan penyuluhan tentang peningkatan pelayanan kesehatan
\end{abstract}

Kata Kunci: Kusta, Pelayanan Kesehatan, Daerah Endemis

\section{ABSTRACT}

The prevalence of leprosy in 2018 was 1.5/10,000 in Tuban. The leprosy elimination program using the MultiDrug Treatment (MDT) method from WHO has been implemented, but new cases of leprosy infection are still found. This is influenced by anthropological and social aspects, which affect the macro-system (government policy), meso (surrounding environment), and micro (hospital and immune system), one of which is the quality of health services by leprosy officers. Counseling was carried out at the Tuban Health Office, which is one of leprosy endemic in East Java. This effort is one of the leprosy control strategies and preventive efforts to break the chain of leprosy transmission by improving the quality of health services in leprosy endemic areas. Counseling was attended by 15 participants who were representatives of each public health center in the Tuban. Counseling was done with education, discussion, and question-answer. To measure understanding, it is used "one group pre and post-test design". The data obtained was analyzed by Wilcoxon Test using SPSS. The average pretest value was $68.67 \pm 9.15$ and posttest was $93.33 \pm 8.16$. Wilcoxon test result showed that all participants experienced an increase in understanding (p-value of 0.001). It is concluded that there is an increased understanding after improving health services counseling.

Keywords: Leprosy, Health Services, Endemic Areas 


\section{PENDAHULUAN}

Di Eropa, sudah terbukti bahwa daerah endemis dapat berubah menjadi non endemis dengan perbaikan sistem layanan kesehatan dan status imunitas (Barua, 2016).

Di Indonesia dan negara-negara lain yang masih tinggi transmisinya, efektivitas perbaikan layanan kesehatan untuk penurunan transmisi kusta masih terganggu oleh stigma maupun keengganan masyarakat endemis untuk secara aktif mendatangi layanan kesehatan (Marahatta, 2018).

Provinsi Jawa Timur merupakan satu satunya provinsi di bagian barat Indonesia dengan angka beban kusta tinggi. Pada tahun 2018, didapatkan prevalensi kusta sebesar 1,5/10.000 di Kabupaten Tuban. Dalam kurun waktu 2014-2019, masih didapatkan kasus kusta baru di Kabupaten yang terletak di pesisir pantai utara Provinsi Jawa Timur tersebut (Kemenkes RI, 2018)

Meskipun telah melaksanakan program eliminasi kusta dengan menggunakan metode Multi Drug Treatment (MDT) dari WHO, namun hingga saat ini masih ditemukan kasus baru infeksi kusta. Diduga hal tersebut dipengaruhi oleh aspek antropologis dan sosial, yang berpengaruh pada sistem makro (kebijakan pemerintah), meso (lingkungan sekitar), maupun mikro (hospes dan sistem imunitas), salah satunya adalah kualitas pelayanan kesehatan oleh para petugas kusta.

Ditawarkan konsep solusi yaitu memberikan penyuluhan mengenai pentingnya meningkatkan pengetahuan tentang kualitas pelayanan kesehatan yang diberikan oleh para petugas kusta untuk mengatasi hal tersebut. Sasaran dari penyuluhan ini yaitu para petugas kusta di Kabupaten Tuban, yang merupakan salah satu daerah kantong endemis kusta di daerah Jawa Timur.

\section{TUJUAN DAN MANFAAT}

Penyuluhan ini dilaksanakan di Kantor Dinas Kesehatan Kabupaten Tuban karena Kabupaten Tuban merupakan salah satu daerah kantong endemis kusta di daerah Jawa Timur.

Upaya penyuluhan ini merupakan salah satu strategi pengendalian penyakit kusta serta sebagai upaya preventif guna memutus rantai penularan kusta dengan cara meningkatkan pelayanan kesehatan di daerah endemis kusta.

Tujuan jangka pendek diadakan penyuluhan tentang pentingnya pelayanan kesehatan untuk meningkatkan pengetahuan para petugas kusta 
tentang tata cara dan keterampilan petugas kusta dalam memberikan pelayanan terhadap penderita kusta. Seperti yang diketahui bahwa terdapat tiga aspek penting dalam pelayanan kesehatan, yaitu aspek penegakan diagnosis secara klinik maupun pemeriksaan bakteri tahan asam (BTA), aspek penatalaksanaan terapi dan komplikasi infeksi kusta, serta aspek promotif preventif, dalam hal ini adalah konseling, informasi, dan edukasi.

Tujuan jangka panjang dari penyuluhan ini adalah memberikan bekal kepada para petugas pelayanan kusta agar mendapatkan pengetahuan yang cukup sebagai upaya preventif terhadap penularan kusta.

\section{METODE PELAKSANAAN KEGIATAN}

Metode yang digunakan pada kegiatan pengabdian masyarakat ini adalah penyuluhan dan tanya jawab dengan para petugas kesehatan Kabupaten Tuban. Sasaran penyuluhan adalah para petugas pelayanan kesehatan di tiap puskesmas Kabupaten Tuban. Pemberian materi dilakukan dengan menggunakan metode dialog interaktif serta diskusi dan tanya-jawab.

Evaluasi terhadap hasil kegiatan diukur melalui hasil kuesioner sebelum dan sesudah dilakukan konseling, diskusi, dan tanya-jawab.
Jenis penelitian ini merupakan quasi experimental dengan rancangan penelitian one group pre and post test design. Nilai yang didapatkan kemudian dianalisis menggunakan uji Wilcoxon menggunakan software SPSS.

\section{HASIL DAN DISKUSI}

Kegiatan penyuluhan ini telah dilaksanakan pada hari Jumat tanggal 5 Maret 2020 di kantor Dinas Kesehatan Kabupaten Tuban, Jawa Timur.

Kegiatan ini diikuti oleh 15 peserta yang masing - masing peserta adalah perwakilan tiap puskesmas di wilayah Kabupaten Tuban. Hasil konseling dan pemberian edukasi terhadap peserta, didapatkan mean/rerata nilai pre test sebesar $68,67 \pm 9,15$, sedangkan mean/rerata nilai post test sebesar $93,33 \pm 8,16$.

Hasil uji Shapiro-Wilk untuk menilai normalitas data, didapatkan $\mathrm{p}=0,050$ untuk nilai pretest dan $p=0,01$ untuk nilai post test, sehingga data dinyatakan tidak terdistribusi normal. Oleh karena itu, analisis yang digunakan untuk membandingkan kedua kelompok adalah uji non parametrik wilcoxon.

Hasil uji wilcoxon terhadap pemberian materi pentingnya peningkatan pelayanan kesehatan, diketahui bahwa seluruh peserta 
memperoleh nilai post test yang lebih besar daripada nilai pre test dengan $\mathrm{p}=0,001$.

\section{PEMBAHASAN}

Metode yang digunakan pada kegiatan pengabdian masyarakat ini adalah penyuluhan dan tanya jawab dengan para petugas kesehatan Kabupaten Tuban. Pelaksanaanya dilakukan di kantor Dinas Kesehatan Kabupaten Tuban pada tanggal 5 Maret 2020. Evaluasi terhadap hasil kegiatan dapat dilihat dari tanya jawab antara penyuluh dengan peserta setelah dilakukan konseling, informasi, dan edukasi. Pemberian materi dilakukan dengan menggunakan metode dialog interaktif. Pengabdian masyarakat ditutup dengan diskusi dan sesi tanya jawab yang diikuti oleh peserta dengan antusias. Perlu dilakukan lebih banyak lagi penyuluhan mengenai pentingnya meningkatkan pengetahuan tentang kualitas pelayanan kesehatan yang diberikan oleh para petugas kusta disertai dengan peningkatan fasilitas yang memadai. Hal tersebut merupakan salah satu tindakan promotif dan preventif untuk membantu memutus transmisi infeksi kusta di daerah endemis

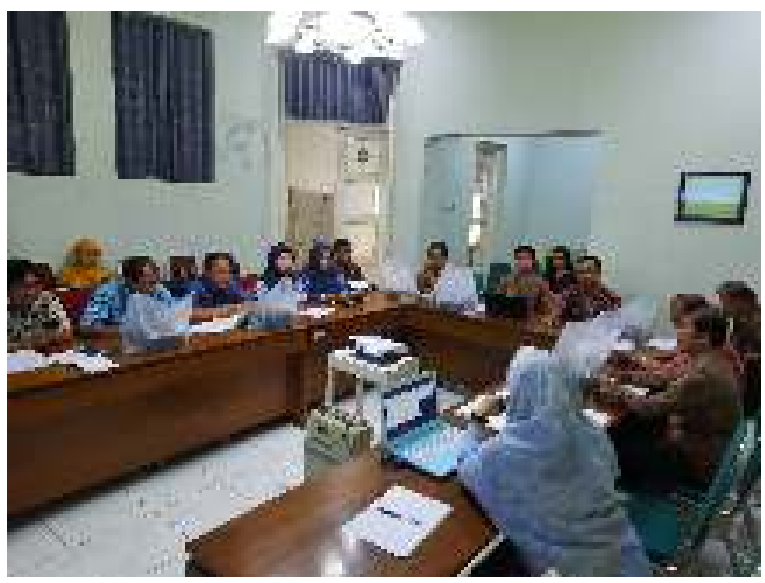

Gambar 1: Sesi Konseling Penyuluh Kepada Peserta Penyuluhan

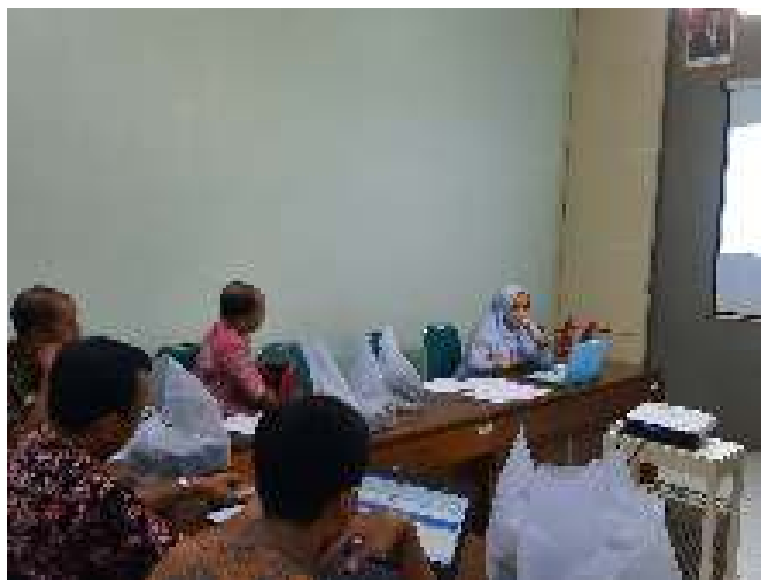

Gambar 2: Pemberian Materi Dan Edukasi Kepada Peserta

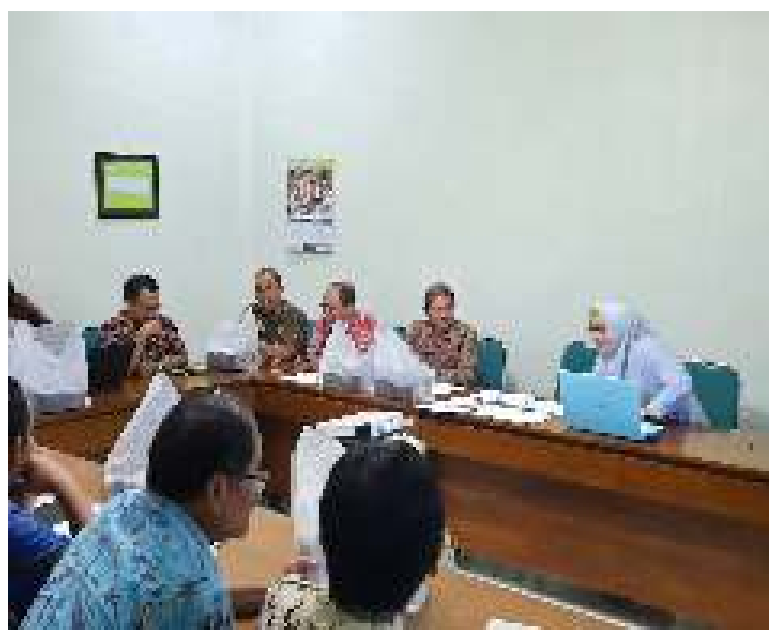

Gambar 3: Sesi Tanya Jawab Peserta Penyuluhan

SIMPULAN DAN SARAN

Perlu dilakukan lebih banyak lagi penyuluhan mengenai pentingnya meningkatkan pengetahuan tentang kualitas pelayanan 
kesehatan yang diberikan oleh para petugas

kusta disertai dengan peningkatan fasilitas yang

memadai. Hal tersebut merupakan salah satu

tindakan promotif dan preventif untuk

membantu memutus transmisi infeksi kusta di

daerah endemis

\section{UCAPAN TERIMAKASIH}

Penyuluhan ini dilaksanakan atas

kerjasama Departemen Ilmu Kesehatan Kulit

dan Kelamin Fakultas Kedokteran Universitas

Muhammadiyah Surakarta dengan Dinas

Kesehatan Kabupaten Tuban. Kami ucapkan

terima kasih kepada pihak-pihak yang telah

membantu dalam kegiatan pengabdian

masyarakat ini.

\section{DAFTAR PUSTAKA}

Abeje T, Negara E, Kebede E, Hailu T, Hassen I, Lema T, Yamuah L, Shiguti B, Fenta
M, Negasa M, Beyene D, Bobosha K, Aseffa A, 2016. Perfomance of General Health Workers in Leprosy Control Activities at Public Health Facilities in Amhara and Oromia States, Ethiopia, BMC Health Service Research, vol 16, no. 122, pp. 1-7.

Barua S, 2016. Global Leprosy Situation: Historical Perspective Achievements, Challenge and Future Steps. In: IAL Textbook of Leprosy. Edisi kedua, pp. 3334.

Kemenkes RI, 2018. Pedoman Nasional Program Pengendalian Penyakit Kusta, Direktorat Jenderal Pengendalian Penyakit dan Penyehatan Lingkungan, Jakarta.

Marahatta SB, Amatya R, Adhikari S, Diri D, Lama S, Kaehler N, Rijal KR, Marahatta S, Adhikari B, 2018. Perceived stigma of leprosy among community members and health care providers in Lalitpur district of Nepal: A qualitative study, Plos One, vol. 13, no. 12, pp. 1-13.

Meima, A, Irgens, LM, van Oortmarssen, GJ, Richardus, JH, \& Habbema, JDF, 2002. Diasppearance of leprosy from Norway: An exploration of critical factors using an epidemiological modelling approach. International Journal of Epidemiology, vol. 31, no. 5, pp. 991-1000. 